\title{
Improving EFL Writing Through Study of Semantic Concepts in Formulaic Language
}

\author{
Andrew D. Schenck ${ }^{1} \&$ Wonkyung Choi ${ }^{1}$ \\ ${ }^{1}$ English Education, Department of Liberal Arts Education (LAEC), Ju Si-gyeong College, Pai Chai University, \\ Daejeon, South Korea \\ Correspondence: Wonkyung Choi, English Education, Department of Liberal Arts Education (LAEC), Ju \\ Si-gyeong College, Pai Chai University, Daejeon, South Korea. Tel: 010-3426-0857. E-mail: wkchoi@pcu.ac.kr
}

Received: October 28, 2014 Accepted: November 28, 2014 Online Published: December 17, 2014

doi:10.5539/elt.v8n1p142 URL: http://dx.doi.org/10.5539/elt.v8n1p142

\begin{abstract}
Within Asian EFL contexts such as South Korea, large class sizes, poor sources of input and an overreliance on the Grammar-Translation Method may negatively impact semantic and pragmatic development of writing content. Since formulaic language is imbued with syntactic, semantic and pragmatic linguistic features, it represents an ideal means to evaluate the influence of Asian EFL contexts on writing. Thus, formulaic language within academic texts from Korean university students was compared to that found in essays written by American university students. Results revealed that Korean EFL learners overused transitions to define the organization of academic texts at the expense of developing content. Moreover, they used repetition, general lists, and all-purpose formulaic language to "pad" content, neglecting to consider semantic or pragmatic purposes of the text. In contrast to their Korean EFL counterparts, American university students used formulaic language for a variety of pragmatic purposes such as involving the reader, putting examples into a larger perspective, adding connotation, and addressing the perspective of the reader. It appears that EFL contexts such as South Korea require pedagogical and curricular reforms which foster the development of writing composition for semantic and pragmatic purposes.
\end{abstract}

Keywords: Asia, EFL, semantic, pragmatic, writing, grammar-translation, South Korea

\section{Introduction}

Cultivating good academic writing skills has historically been a challenge for English learners in South Korea (Oak \& Martin, 2003). Large class sizes have severely limited the degree to which students can interact with instructors and receive feedback. While the number of students in each classroom was reduced a decade ago, sizeable classes of 35-40 still continued to predominate in most Korean middle and high schools (Cho, 2004). Some classes remain large today, particularly in school districts with limited funding or facilities to accommodate young learners.

In addition to class size, extensive instruction via the Grammar-Translation Approach has presented challenges. While educators in Asian countries such as South Korea and China are now aware of innovative pedagogical practices to improve student writing, they tend to rely on conventional methods of instruction and feedback that focus on language form (Lee, 2014). The continued emphasis on grammar and translation has not only influenced learners' written communication, but their conception of effective writing principles. Concerning these principles, Tyson (2003) wrote that, "when I ask my [Korean EFL] students what they hope or expect to learn in my composition classes at the beginning of a new semester, nearly all of them mention grammar" ( $p$. 115). In actuality, this statement is a reflection of pedagogical overemphasis on language form, which has left learners with an impression that grammar is the primary means to produce quality writing.

Although emphasis on grammar in the writing process is needed, it represents merely one facet of a much more complex process. Overemphasis of syntax, as well as extensive rote memorization of vocabulary, limits understanding of top-down processes related to discourse and pragmatics. Essentially, the excessive literal interpretation of individual linguistic forms prevents comprehension of language as a whole. This issue is illustrated through a recent conversation between an American and Korean EFL student:

American: I'm so happy that you made these cookies! 


\section{Korean: Then you should say thank you!}

\section{American: I thought I just did.}

In this example, the Korean speaker shows a clear understanding of the grammar and surface meaning. The speaker, however, is unable to grasp the top-down, illocutionary purpose of the American's comment, which was made to express thanks. Failures such as these may be expected in countries that primarily emphasize grammar at the expense of semantic concepts. This explains research citing extensive pragmatic failures among Asian learners (Zheng \& Huang, 2010). Because semantic and pragmatic failures may form a significant barrier to effective written communication, more innovative and effective pedagogical techniques are needed in EFL contexts. Before these techniques may be designed, however, the influence of various contextual factors on writing must be further examined.

\subsection{Research Problem}

In addition to bottom-up learning concepts such as grammar, it is essential that writers gain top-down knowledge of L2 discourse, pragmatics, and culture (Celce-Murcia \& Yoo, 2014). Because formulaic language is a reflection of all these concepts, it can be further studied to expand our understanding of writing development, influences of the writing process, and appropriate pedagogical strategies to enhance writing ability. The following questions have been posed to study writing in an Asian EFL context:

1) How does formulaic language in EFL academic writing differ from that found in native English contexts?

2) Why does formulaic language use differ? What do disparities in formulaic language use reveal about the writer's understanding of semantic concepts and discourse?

3) How can an understanding of formulaic language be used to improve pedagogy and evaluation in Asian EFL contexts?

Because EFL environments differ from those found in an ESL context, study within these contexts may reveal how differing input and pedagogical practices influence the writing process. This understanding may subsequently be used to develop more effective forms of writing instruction.

\section{Literature Review}

Initially, methods of language instruction focused upon rote memorization, grammar drills, and translation of L2 texts into the learner's mother tongue (Celce-Murcia, 1991). In the 1960's, however, it became apparent that such instruction was not effective as a means to improve speech or writing. Regardless of the instructional techniques applied, learners appeared to acquire linguistic features in a set order, which was hypothesized to be the manifestation of an innate Language Acquisition Device (LAD) (Chomsky, 1975, 1981, 1986; Cook, 1993; Dulay \& Burt, 1974; Dulay, Burt, \& Krashen, 1982). As support for the presence of LAD grew, so did theories advocating the modification of learner input and tasks according to a learner's developmental level (Dulay \& Burt, 1973; Krashen \& Terrell, 1983; Pienemann, 1999, 2005).

Despite the valuable insight gleaned from research of language acquisition, the most effective means to modify instructional input and tasks to improve writing still remains unclear. This uncertainty is exemplified by the perpetuation of an intense debate over error feedback (Van Beuningen, DeJong, Kuiken, 2012; Bitchener, Young, \& Cameron, 2005; Ferris, 2004; Truscott, 1996, 1999). Researchers such as Truscott $(1996,1999)$ have concluded that explicit grammar correction is superfluous in the writing process, while others have vehemently refuted this claim (Bitchener, Young, \& Cameron, 2005; Ferris, 2004). In reality, the debate appears to be fueled by a limited focus merely on syntax, which neglects consideration of other factors that influence grammar development. Such a limited view makes interpretation of inconsistencies with pedagogical treatments challenging. To address this issue, recent research has taken a more holistic approach to the study of grammar. Recent studies, for example, have begun to simultaneously evaluate the importance of both semantic and syntactic concepts in the process of language production (Cuza, Guijarro-Fuentes, Pires, \& Rothman, 2013; Gil \& Marsden, 2010; Han \& Liu, 2013; Ko, Perovic, Ionin, \& Wexler, 2008).

While aspects of semantics and syntax are synergistically responsible for grammar development, they are also just as important for the development of lexical elements within writing. This is exemplified by a study revealing that language learners utilize semantic understanding from their L1 to interpret relationships between both syntactic and lexical elements of their L2 (Jiang, 2004). Since syntax, semantics, and lexical units are all vital elements of language development, researchers such as Kecskes (2007) have sought to integrate and understand these factors through the development of a formulaic continuum (Table 1). 
Table 1. Formulaic continuum (Kecskes, 2007, p. 3)

\begin{tabular}{llllll}
\hline $\begin{array}{l}\text { Grammatical } \\
\text { Units }\end{array}$ & $\begin{array}{l}\text { Fixed Semantic } \\
\text { Units }\end{array}$ & Phrasal Verbs & $\begin{array}{l}\text { Speech } \\
\text { Formulas }\end{array}$ & $\begin{array}{l}\text { Situation-Bound } \\
\text { Utterances }\end{array}$ & Idioms \\
\hline Be going to & As a matter of fact & Put up with & Going shopping & Welcome aboard & Kick the bucket \\
\hline Have to & Suffice it to say & Get along with & Not bad & Help Yourself & Spill the beans \\
\hline
\end{tabular}

As the continuum moves from left to right, the degree of semantic complexity increases. On the left side of the continuum, grammatical units such as "have to" appear to have a direct relationship between their syntax and meaning. On the right side of the continuum, however, Situation-Bound Utterances (SBUs) (lexical units used in precise pragmatic situations) and idioms reveal little connection between their individual constituents and meaning. The more highly complex formulaic sequences at the right of the continuum include not only less salient semantic characteristics, but cultural and pragmatic meaning. Consider an idiom such as, "Rome wasn't built in a day." It conveys a sense that the creation of great things takes time. The understanding that Rome is a "great thing" or a tremendous feat of engineering, however, is deeply rooted in a conception based upon Western civilization. Because such idiomatic expressions are imbued with cultural and pragmatic information, they may be very difficult for Asian EFL learners to acquire.

Collectively, all of the grammatical and semantic units within the continuum in Table 1 are needed to effectively communicate. Not only is formulaic language used to convey semantic meaning, it is used to organize discourse (e.g., fixed semantic units or transitions), culturally connect to others (e.g., idioms), and serve pragmatic functions (e.g., SBUs). Research also confirms that such language is a ubiquitous part of writing, comprising more than 50\% of most written discourse (Biber, 2009; Durrant, \& Mathews-Aydınl,, 2011; Schmitt, 2004). Since formulaic language is so prevalent within writing, and includes a variety of semantic and syntactic elements, it represents an ideal tool for evaluation. Thus, study of formulaic language may help reveal the effectiveness or ineffectiveness of input and pedagogical techniques used to cultivate English writing skills.

\subsection{Formulaic Language in an EFL Context}

Recent studies clearly reveal the effectiveness of explicit pedagogical techniques on the development of formulaic language and fluency (Li \& Schmitt, 2009; Wood, 2007, 2008, 2009; Wray, 2000). The sole use of participants within ESL contexts, however, has provided only a limited perspective. Although ESL contexts contain a rich environment for the acquisition of formulaic language, EFL contexts often contain input that is scant or highly different from that found in native English contexts. Furthermore, the commercial book market produces resources of low quality that do not properly prepare EFL learners to write effectively (Chen, 2007; Cho \& Shin, 2014).

In addition to issues with input, pedagogical strategies within EFL contexts may inhibit development of formulaic language, along with its associated semantic, pragmatic, and cultural content. In Asian countries such as South Korea, Japan, and China, college entrance exams often drive the use of the Grammar-Translation Approach (Watanabe, 1996). Via this method, English sentences are "dissected" into their constituent parts and processed individually, rather than collectively to produce communicative discourse. Since this type of instruction emphasizes a bottom-up approach, it may severely limit understanding of top-down processes used to produce larger lexical expressions and written compositions.

Because issues within Asian EFL contexts today make learning formulaic language and associated top-down semantic concepts problematic, it is essential that additional research be conducted. This research can ascertain influences of variable input and pedagogical practices on the development of formulaic language and semantic concepts in writing. Results of such study, in turn, may lead to the development of new pedagogical approaches for composition which accommodate the unique needs of Asian EFL learners in countries such as South Korea, China, and Japan.

\section{Method}

\subsection{Materials}

In order to analyze texts written by both native English and Korean EFL university learners, the Louvain Corpus of Native English Essays (LOCNESS) and the Gachon Learner Corpus (GLC) were used respectively (Carlstrom, 2013; Centre for English Corpus Linguistics, 2014). LOCNESS includes essays from a variety of genres written by British and American university students. The learners selected from this corpus were all native speakers of English who studied at Presbyterian College in South Carolina. Like LOCNESS, the GLC includes academic 
texts from a variety of genres. These texts, however, are generally one paragraph in length and were written by EFL learners. All of the learners included in this corpus studied at Gachon University, which is located near Seoul, South Korea.

\subsection{Operational Definition of Variables}

Formulaic language is defined as, "a segment of language made up of several morphemes or words which are learned together and used as if they were a single item" (Richards \& Schmidt, 2013, p. 503). In accordance with this definition, groups of morphemes or groups of words that formed single semantic units were systematically studied within each text of the selected corpora. To enhance understanding of language use within writing, the following types of formulaic expressions were selected from Table 1 and operationally defined as follows:

1) Fixed Semantic Units-Multiword units that cannot be changed (e.g., "As a matter of fact,")

2) Phrasal Verbs - Verbs with a particle (not verbs with a preposition) (e.g., "turn the light off")

3) Speech Formulas - Collocations which include "slots" or segments that may be altered (e.g, “... stand in the way of (your dreams)")

4) Idioms - A group of words with a meaning which is not discernible from constituent parts (e.g., "Paint a colorful picture of (life in the 18th century)")

Since singular grammatical features (e.g., "have to") do not clearly reveal top-down semantic concepts in academic writing, and SBUs (e.g., "Help yourself") are often closely associated with situational contexts in oral communication, these features of the formulaic continuum were not selected for study.

\subsection{Procedure}

Since corpora that could be both quantitatively and qualitatively studied were needed, subsections of each corpus were selected. From the LOCNESS corpus, a subcorpus obtained from Presbyterian College in South Carolina was chosen. This corpus includes essays from 8 different learners which were collected in 1995 . The first 16 essays comprised a corpus of 1,776 words. While the corpus was large enough to provide rich quantitative data, it was also small enough so that each text could be qualitatively analyzed in detail. The essays were of mixed themes, but related mostly to different forms of literature.

To select a subsection from the GLC, the most advanced Korean learners who had not studied abroad were chosen. The most advanced learners were selected with the assumption that their writings would include the greatest amount of semantic complexity, while learners who had not studied abroad were selected to minimize the chance that input from native English contexts could influence the use of formulaic language. Determinations of proficiency level were made by selecting students with the highest TOEIC scores. These scores ranged from $800-925$ and included 9 different students. Seventy-eight texts from these students, in the form of academic paragraphs of mixed genres, created a corpus of 1,754 words. The similarity in size of the GLC corpus selection with that of LOCNESS (1,776 words) made direct comparison of frequency values possible. The smaller sample size of both corpora also allowed for comprehensive qualitative analysis of the texts.

After the corpora were selected for study, formulaic language was systematically located and analyzed. To provide the most comprehensive view of formulaic language use, a search for semantic sequences was conducted in two steps. In the first step, a simple concordance program was used to look at individual words and word frequencies. Formulaic patterns were analyzed qualitatively through referencing the words in context. In the second step, each text was carefully examined so that larger semantic units of the formulaic continuum (fixed semantic units, phrasal verbs, speech formulas, and idioms) could be counted. After the numbers of each type of unit were tallied, quantitative patterns were qualitatively examined.

Following quantitative and qualitative analysis of formulaic language use, results from each corpus were contrasted to examine how and why formulaic language differed between the two groups of writers (research questions one and two). The results were then organized and summarized. Issues concerning the use of formulaic language among Korean EFL learners were outlined, along with pedagogical interventions needed to assist these and other learners from similar contexts (research question three).

\section{Results and Discussion}

Analysis of word frequencies and patterns revealed several key differences between Korean EFL learners and their native English counterparts. One major difference was the use pronouns and determiners (Figure 1). 


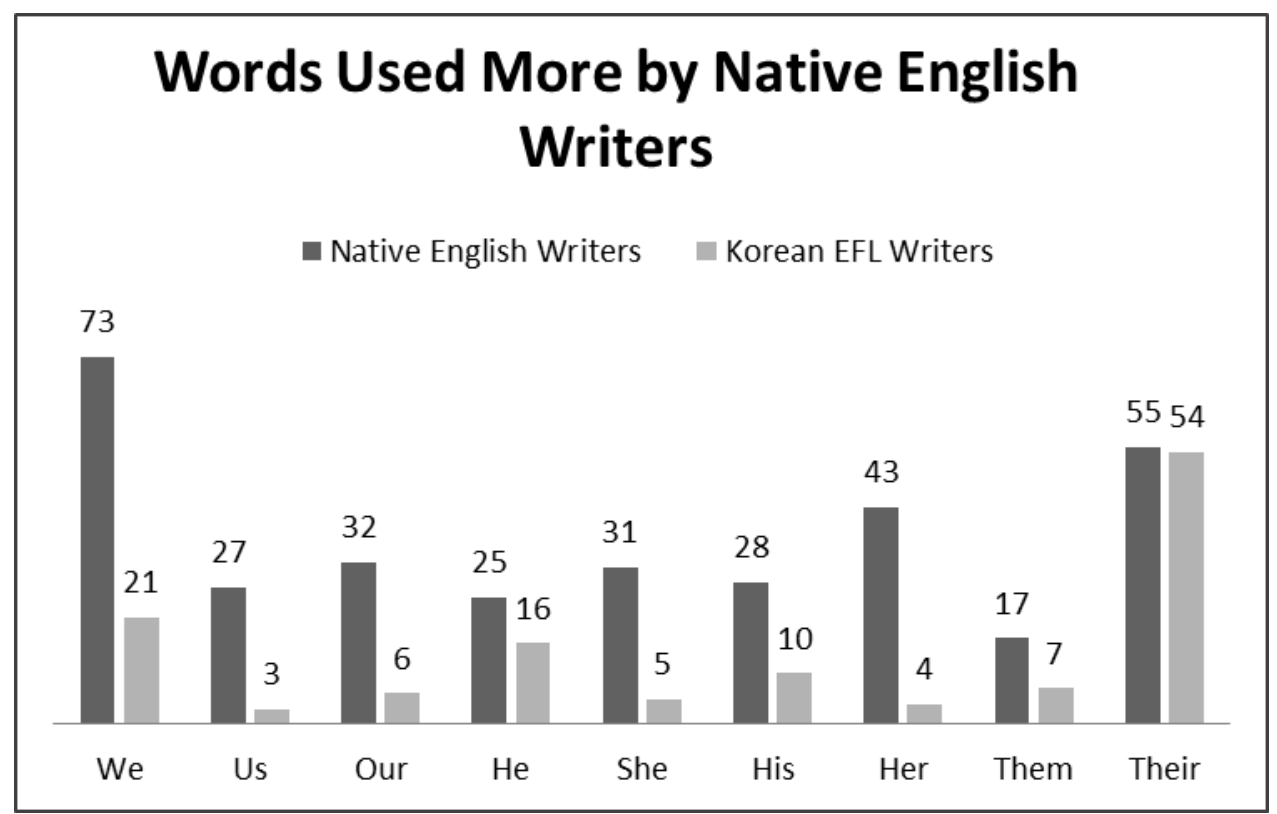

Figure 1. Words used more frequently by native English writers

Not only did American learners use a larger variety of pronouns and determiners such as we, us, our, he, she, his, her, them and their, they used this type of grammatical feature more often. Native English learners, unlike their Korean EFL peers, utilized these grammatical features for pragmatic purposes. Pronouns and determiners were used to define differing social groups, ideas, or perspectives. This may best be illustrated by using the following examples obtained through concordance analysis of LOCNESS:

1) ...time in which to accept his own misconceptions and to...

2) ...one can relate these to one's own experiences and identities...

3) ...thereby broadening one's own knowledge about oneself...

4) ...gift to the people of their own background, as well as and...

5) ...not only to their own race but just as...

6) ...especially of those in our own "backyards". People like...

7) ... on which we can reexamine our own feelings towards these...

The possessive determiner is used in expressions such as "our own backyards" and "our own feelings" to establish a social connection and sense of commonality with the reader. For expressions such as "his own misconceptions," "their own race," and "their own background," the possessive determiner is used to describe social circles, groups, or perspectives that differ from the reader. Finally, expressions which use the determiner one's, as in "one's own knowledge" and "one's own experiences," establish a socially "neutral" opinion. While native English writers were able to utilize pronouns and determiners to explain social relationships from the reader's perspective, Korean learners tended to write from their own singular point of view. This is exemplified by their overuse of the pronouns $I$ and $m e$. The subject pronoun $I$ was used eight times more often in the EFL compositions (386 to 45 times respectively); the object pronoun me was used 20 times more often (40 to 2 times respectively). Although Korean EFL learners did use other pronouns such as they to describe people within their academic texts, these grammatical features appeared to serve little pragmatic purpose. Instead, they were simply used to express general concepts such as "other people."

In addition to explaining groups and individuals from the reader's perspective, native English writers used a variety of words to either support an opinion or add negative/positive connotations to information given. In one text, for example, a learner stated that ethnic American literature cannot "merely" be categorized as "rebellious responses to oppression." In this example, the native English writer used the word merely to relegate the following phrase to an inferior position. As in the case of the word merely, many other words such as conflict, conform, war-torn, torment, confront, cope, dehumanizing, denounce, embrace, repercussions, shun, sacred, subservience, thought-provoking, truly, and whole-heartedly were used to intensify importance or imbue 
connotation to the concepts covered. Use of these words does not only indicate increased proficiency, it suggests an extra pragmatic ability to add degrees of significance to their perspectives.

Unlike their native English peers, Korean EFL university students did not often describe different groups, social circles, or perspectives in detail. Furthermore, they appeared to have difficulty adding positive and negative connotations to concepts explained within their texts.

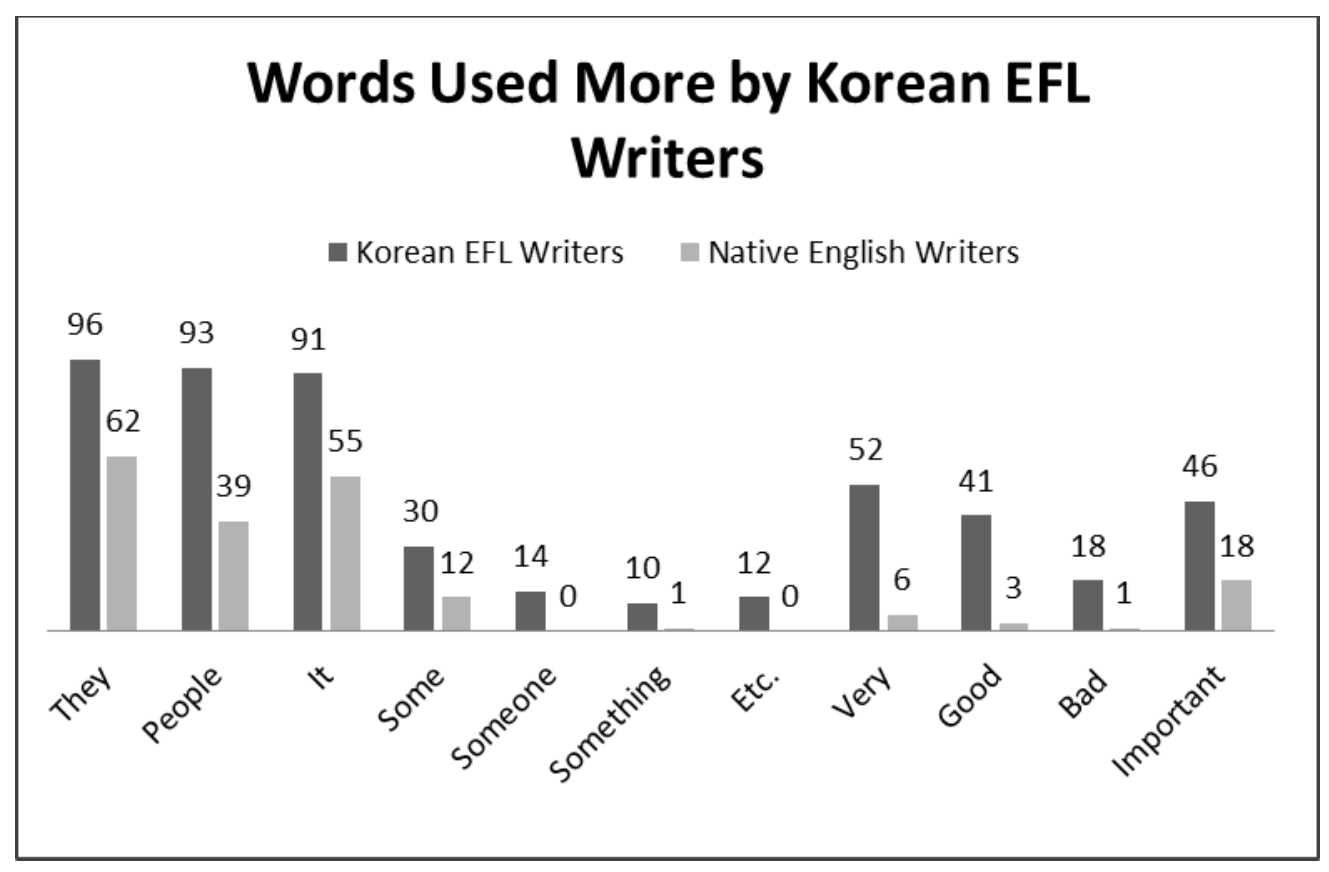

Figure 2. Words used more frequently by Korean EFL writers

More extensive use of the words in Figure 2 suggests that Korean EFL learners had difficulty adding specificity to texts. Words such as they, people, it, some, someone, and something were used as "all-purpose" words to describe main concepts. Likewise, words such as etc., important, good, and bad were used to describe the state of general situations or examples without adding more detailed information or connotation. The preference for general concepts over specific, detailed examples when supporting an argument is further exemplified by the following academic paragraph taken from the GLC:

The best way for someone to improve one's appearance is neatness. For example, there is a man. The man is goodlooking and good at speaking. But, if he is not wash hair and clothes, many people don't like him. ... So improving one's appearance is very important and that best way is neatness. The other way is go to clinic center. Although the money is needed, but result is very effective ... so if someone want to improve one's appearance, effective way is go to clinic center. He or she is gaven massage and nail care and pedicure, and haircut, etc. going salon is effective way too [sic].

All-purpose lists, repetition of similar concepts, and expressions such as etc. in this paragraph allow the writer to produce vague general ideas to support their argument, rather than more detailed explanations of specific concepts which may involve the reader. Moreover, the relatively neutral terms such as one's appearance, the man, and someone do not specifically explain relationships according to the reader's perspective. As a result of this writing style, there appears to be a general disconnect between the reader and the content presented in the text.

Overall, analysis of individual words suggests that native English writers possess pragmatic skills that Korean EFL learners lack. First, American students can utilize words and other expressions to describe groups and situations from a variety of perspectives, including that of the reader. Second, American learners have a larger repertoire of words that can add differing connotations of various intensity levels. Such pragmatic writing skills appear to help the reader build a schema from which they can become involved with, and make judgments about, the text. 


\subsection{Larger Semantic Expressions}

Like analysis of individual words, studies of semantic expressions within the formulaic continuum (fixed semantic units, phrasal verbs, speech formulas, and idioms) revealed several key differences (Table 2).

Table 2. Different types of formulaic expressions found in text

\begin{tabular}{lllll}
\hline & Fixed Semantic Units & Phrasal Verbs & Speech Formulas & Idioms \\
\hline Native English Writers & 59 & 40 & 125 & 36 \\
\hline Korean EFL Writers & 122 & 11 & 189 & 6 \\
\hline
\end{tabular}

From looking at Table 2, it is obvious that Korean EFL learners more extensively used fixed semantic units than their native English peers. These units were comprised primarily of transitions such as "First of all" or "However." Instead of explaining situations in detail or emphasizing content, Korean EFL learners appeared to concentrate on using fixed semantic units to "prove" academic writing proficiency. Refer to the following example from the GLC:

First of all, I think their personality affect color that they like or dislike. For example, if some people are introverts, they like gloomy color like black and grey. In contrast, if some people are extroverts, they like bright color like yellow and white etc. Second, people like color that go well with them. For instance, I really like purple and red because they are good color on me and I don't like brown and pink because they aren't the ones that look good on me. As a result, I think there are many factors that affect like color and dislike color [sic].

The learner appears to use transitions to demonstrate that the writing has the correct academic organization, rather than elaborating on concepts in a sequence which reveals a cohesive structure. Very little attention is given to the expansion of content (e.g., etc. is used to avoid further exploration of color preferences). As a result, texts from the EFL learners look more like a skeletal representation of academic writing, rather than a substantial exploration of content or ideas.

Native English writers relied less on the use of transitions to reveal structure, opting to explore content in a sequence that revealed coherence. The emphasis of content over the use of fixed semantic units explains the larger use of both phrasal verbs and idiomatic expressions by native English writers (Table 2). One writer, for example, used expressions such as "break away from social injustice" and "faced with an examination of his own role" to elaborate upon the struggles faced by minorities. The cultural and pragmatic associations of these expressions with the concept "challenge" helped to reinforce coherence without the need to utilize extensive transitions. Native English writers also utilized culturally-loaded idiomatic expressions to connect with the reader and cultivate interest in content. In the phrase, "Our country has been coined a melting pot," coined is used as a means to introduce additional cultural information that is assumed to be shared by the reader and author While such techniques were generally not present within Korean EFL texts, one author did state that, "In Korea, there is a saying, 'Fat people are unscratched lottery ticket.' Actually there are many peoples [sic] who improve one's figure by dieting." Although this learner does use a cultural saying, he fails to elaborate upon precisely what it means or how it relates to the text, and simply assumes that it will be understood by the reader.

In addition to detailed expansion of content and the utilization of semantically more complex expressions, native English writers utilize formulaic language for a larger variety of pragmatic purposes (Table A1). While both native English writers and Korean EFL learners used formulaic language for presenting sequences, comparing, contrasting, providing examples, emphasizing importance, expressing an opinion, and showing cause and effect, native English writers used a variety of additional formulaic units for pragmatic purposes. American students, for example, exemplified processes through expressions such as, "in this way" or "in this manner." These learners also presented alternate perspectives from the views of other individuals, social groups, or the majority. In addition to elaboration of different societal perspectives, native English writers tried to involve and interest the reader by revealing fresh viewpoints through expressions such as, "open our eyes to," "under the surface," and "one wonders how." Finally, native English writers relied on formulaic expressions such as "as a whole" or "draws together" to incorporate themes and provide a more general perspective of discreet elements within the text. These expressions were preferred to maintain coherence over the mechanical, sequential transitions favored by Korean EFL learners.

In closing, comparison of native English and Korean EFL writers' use of formulaic language reveals several noteworthy differences that may be utilized to improve instruction and evaluation. On the whole, Korean EFL 
learners' use of formulaic language reveals academic writing that is only mechanically proficient. Formulaic transitions are used to explicitly denote sequences and maintain unity of content. The underlying simplicity of this content suggests that these learners do not have a good understanding of how to develop discourse or pragmatic concepts within English writing. They may also lack knowledge of the formulaic expressions needed to address such issues with content. Because traditions of writing in Asian countries like Korea, China and Japan value artistic expression through spiral logic and circumlocution (Bennett, 2007), students may be unaware of exactly how to elaborate on content in ways that maintain unity. Students may also have been hindered from using concepts related to pragmatics and discourse due to a historical overemphasis of grammatical forms.

Differences in discourse and cultural writing styles, along with an overemphasis of grammar at the expense of semantic and pragmatic concepts, appear to have negatively impacted EFL learners within South Korea. These issues explain the dearth of idioms and less semantically transparent expressions within compositions. They also explain the general lack of formulaic language for the presentation of different perspectives or elaboration of ideas. Due to clear subject matter deficiencies within Korean EFL writing, it is essential that curricula be reformed to promote pragmatic and semantic development of content.

\section{Conclusion}

Analysis of writing suggests that Korean EFL learners use formulaic language to delineate basic structure of text and provide simplistic examples. These learners, however, appear to lack the means to strengthen academic writing through elaboration of content. Results suggest that Korean EFL learners who have been educated through the Grammar-Translation Approach have difficulty integrating cultural and pragmatic concepts within writing.

Unlike their EFL counterparts, native English university learners have the ability to interest and involve the reader through: presenting idiomatic expressions that exemplify a point, presenting an alternate perspective from the view of various social groups or individuals, expressing a degree of certainty, describing a process, revealing new information to the reader, involving the reader, and putting examples into a larger perspective. Because these skills can produce superior content, it is essential that they be cultivated in EFL learners as they progress to more advanced levels.

While a basic understanding of structure is necessary, it may be rendered useless if a writer is not able to achieve an intended pragmatic purpose. As the importance of English as a lingua franca grows, so do the needs to solve such practical, real-world problems. Since EFL learners may not have encountered pragmatic and cultural concepts needed to write effectively, and may have learned other circular means of discourse in their L1, educators need to utilize writing curricula that move beyond a simplistic focus on grammar.

Table 3. Sample syllabus for advanced EFL writing

\begin{tabular}{|c|c|c|c|}
\hline Objective & Target Idioms & Target Language Examples & Pedagogical Techniques \\
\hline $\begin{array}{l}\text { 1. Exemplify a Point } \\
\text { through } \quad \text { Using } \\
\text { Idiomatic Expressions } \\
\text { and Definitions }\end{array}$ & $\begin{array}{l}\text { • "Old habits die } \\
\text { hard" }\end{array}$ & $\begin{array}{l}-\quad \ldots \text { is defined as... } \\
-\quad \ldots \text { coin (a phrase)... } \\
\text { - } \quad \ldots \text { as exemplified by } \\
\text { the idiom... }\end{array}$ & $\begin{array}{l}\text { Learners look up an idiom and } \\
\text { use it to prove a point. Learners } \\
\text { may use "Old habits die hard," } \\
\text { for example, to describe the } \\
\text { difficulty of combating an } \\
\text { addiction. }\end{array}$ \\
\hline $\begin{array}{l}\text { 2. Present Another } \\
\text { Perspective }\end{array}$ & $\begin{array}{l}\text { - "Clothes do not } \\
\text { make the man" } \\
\text { - "Don't judge a } \\
\text { book by its cover" } \\
\text { - "One man's } \\
\text { gravy is another } \\
\text { man's poison" }\end{array}$ & $\begin{array}{l}\text { - In most people's } \\
\text { eyes... } \\
\text { - In most cases, } \\
\text { - At the same time, } \\
\text { - As explained by... } \\
\text { - In some cases... } \\
\text { - According to his } \\
\text { view... }\end{array}$ & $\begin{array}{l}\text { Learners are asked to define an } \\
\text { idiom and use it to explain an } \\
\text { individual from varied points of } \\
\text { view. }\end{array}$ \\
\hline $\begin{array}{l}\text { 3. Express Degree of } \\
\text { Intensity or Certainty / }\end{array}$ & $\begin{array}{l}\text { • "Might makes } \\
\text { right" }\end{array}$ & $\begin{array}{l}\cdot \text { Beyond a shadow of a } \\
\text { doubt... }\end{array}$ & $\begin{array}{l}\text { Have students debate the } \\
\text { controversial idioms. Students } \\
\text { will then be encouraged to }\end{array}$ \\
\hline
\end{tabular}




\begin{tabular}{|c|c|c|c|}
\hline Add Connotation & $\begin{array}{l}\text { - "The pen is } \\
\text { mightier than the } \\
\text { sword" } \\
\text { - "A leopard } \\
\text { cannot change his } \\
\text { spots" }\end{array}$ & $\begin{array}{ll}\text { - } & \text { In no way... } \\
\text { - } & \text { To some extent, } \\
\text { - } & \text { On this level... } \\
\text { - } & \text {...just as importantly... } \\
\text { - I } & \text { I would be } \\
\text { hard-pressed to find } \\
\text { anyone... } \\
\text { - } \\
\text { - } \\
\text { Merely } \\
\end{array}$ & $\begin{array}{l}\text { integrate various opinions and } \\
\text { examples with various degrees } \\
\text { of certainty. }\end{array}$ \\
\hline 4. Describe Process & $\begin{array}{l}\text { - "Rome wasn't } \\
\text { built in a day" } \\
\text { - "The first step } \\
\text { is always the } \\
\text { hardest" }\end{array}$ & $\begin{array}{ll}\text { - } & \text {...thereby... } \\
\text { - } & \text {...in such a way that... } \\
\text { - } & \text { In this manner... } \\
\text { - } & \text {... as a way to... } \\
\text { - } & \text { Because of the way... }\end{array}$ & $\begin{array}{l}\text { Students will be taught the } \\
\text { idioms. They are then given a } \\
\text { list of processes to describe } \\
\text { using the target language (e.g., } \\
\text { educational reform) }\end{array}$ \\
\hline $\begin{array}{l}\text { 5. Reveal New and } \\
\text { Unknown Information } \\
\text { to the Reader }\end{array}$ & $\begin{array}{l}\text { - "where there's } \\
\text { smoke, there's fire" } \\
\text { - "the grass is } \\
\text { always greener on } \\
\text { the other side" } \\
\text { - "All that } \\
\text { glitters is not gold" }\end{array}$ & $\begin{array}{l}\text { - } \text { Take, for instance, } \\
\text { - } \quad \text {...under the surface... } \\
\text { - } \quad \text { It gives us a fresh new } \\
\text { perspective on... } \\
\text { - } \quad \text {...give us some insight } \\
\text { into... }\end{array}$ & $\begin{array}{l}\text { Learners use the idioms to } \\
\text { demonstrate a new perspective. } \\
\text { For "the grass is always } \\
\text { greener," learners may be asked } \\
\text { to explore someone they envy } \\
\text { and how that person's life may } \\
\text { not be as good as it really } \\
\text { seems. }\end{array}$ \\
\hline 6. Involve the Reader & $\begin{array}{l}\text { - "You're never } \\
\text { too old to learn" }\end{array}$ & $\begin{array}{ll}\text { - } & \text { Open our eyes to... } \\
\text { - } & \text {...close our eyes to... } \\
\text { - } & \text {...of our people... } \\
\text { - } & \text { One wonders how... } \\
\text { - } & \text {...provides us with... } \\
\text { - } & \text {...shows us how... }\end{array}$ & $\begin{array}{l}\text { Learners can be asked to } \\
\text { involve the reader in their } \\
\text { argument by using the target } \\
\text { language. }\end{array}$ \\
\hline $\begin{array}{l}\text { 7. Put Examples Into } \\
\text { Larger Perspective }\end{array}$ & $\begin{array}{l}\text { - "In unity there } \\
\text { is strength" } \\
\text { - "Look before } \\
\text { you leap" }\end{array}$ & $\begin{array}{l}\text { - } \quad \text { As a whole, } \\
\text { - } \quad \text {...draws together... } \\
\text { - } \quad \text {...as part of... } \\
\text { - } \quad \text { To put the argument } \\
\text { simply... } \\
\text { - } \quad \text { Symbolic of... }\end{array}$ & $\begin{array}{l}\text { Learners can be encouraged to } \\
\text { use the idioms to holistically } \\
\text { analyze an issue. They may, for } \\
\text { example, be encouraged to } \\
\text { write about the strengths of } \\
\text { various individuals and then } \\
\text { draw the information together } \\
\text { to prove the statement, "In unity } \\
\text { there is strength." }\end{array}$ \\
\hline
\end{tabular}

The sample syllabus in Table 3 shows how curricula can be realistically reformed in EFL contexts to enhance pragmatic and cultural competence. Idioms may be used to establish a common cultural background, interest the reader, or introduce the purpose of a text. Formulaic expressions may then be used to further develop content according to the idiom and the text's target objective. Development of content in this way will help EFL students accomplish various pragmatic tasks. It will also help these learners understand the purpose of their writing and the importance of considering content from the perspective of the reader.

While the information presented within this paper is useful as a means to reform curricula in Asian EFL contexts such as South Korea, more study is needed. The paper provides only a limited understanding of linguistic features which can improve the quality of English compositions. Additional corpus studies must be conducted to cultivate a more holistic perspective of the formulaic, pragmatic, and cultural charactersitics of written discourse. Using such a perspective, writing curricula and pedagogy can be significantly enhanced. Because formulaic 
language encodes grammatical, semantic, cultural, and pragmatic information, it also represents an ideal means to improve writing evaluation. In the future, formulaic language may be used to transform education in Asian EFL contexts such as South Korea, which have thus far heavily relied upon methods that emphasize grammar.

\section{References}

Bennett, C. L. (2007). Comprehensive multicultural education: Theory and practice (6th ed.). New York: Pearson Education.

Biber, D. (2009). A corpus-driven approach to formulaic language in English: Multi-word patterns in speech and writing. International Journal of Corpus Linguistics, 14(3), 275-311. http://dx.doi.org/10.1075/ijcl.14.3.08bib

Bitchener, J., Young, S., \& Cameron, D. (2005). The effect of different types of corrective feedback on ESL student writing. Journal of second language writing, 14(3), 191-205. http://dx.doi.org/10.1016/j.jslw.2005.08.001

Carlstrom, B. (2013). Gachon Learner Corpus. Gachon University, South Korea. Retrieved from $\mathrm{http} / / /$ koreanlearnercorpusblog.blogspot.be/p/corpus.html

Celce-Murcia, M. (Ed.). (1991). Teaching English as a second or foreign language (2nd ed.). Boston, Massachusetts: Heinle \& Heinle Publishers.

Celce-Murcia, M., \& Yoo, I. W. (2014). Discourse-based grammar and the teaching of academic reading and writing in EFL contexts. English Teaching, 69(1), 3-21. http://dx.doi.org/10.15858/engtea.69.1.201403.3

Centre for English Corpus Linguistics. (2014). Louvain Corpus of Native English Essays (LOCNESS). Université Catholique de Louvain, Belgium. Retrieved from http://www.learnercorpusassociation.org/resources/ corpora/locness-corpus/

Chen, J. (2007). On how to solve the problem of the avoidance of phrasal verbs in the Chinese context. International Education Journal, 8(2), 348-353.

Cho, B. E. (2004). Issues concerning Korean learners of English: English education in Korea and some common difficulties of Korean students. The East Asian Learner, 1(2), 31-36.

Chomsky, N. (1975). The logical structure of linguistic theory. New York, NY: Plenum.

Chomsky, N. (1981). Lectures on government and binding. Dordrecht, Netherlands: Foris.

Chomsky, N. (1986). Knowledge of language: Its nature, origin, and use. New York, NY: Praeger.

Cho, H. Y., \& Shin, J. A. (2014). Cohesive devices in English writing textbooks and Korean learners' English writings. English Teaching, 69(1), 41-59. http://dx.doi.org/10.15858/engtea.69.1.201403.41

Cook, V. (1993). Linguistics and second language acquisition. New York, NY: Palgrave.

Cuza, A., Guijarro-Fuentes, P., Pires, A., \& Rothman, J. (2013). The syntax-semantics of bare and definite plural subjects in the L2 Spanish of English natives. International Journal of Bilingualism, 17(5), 634-652. http://dx.doi.org/10.1177/1367006911435594

Dulay, H. C., \& Burt, M. K. (1973). Should we teach children syntax? Language Learning, 23(2), 245-258. http://dx.doi.org/10.1111/j.1467-1770.1973.tb00659.x

Dulay, H. C., \& Burt, M. K. (1974). Natural sequences in child language acquisition. Language Learning, 24(1), 37-53. http://dx.doi.org/10.1111/j.1467-1770.1974.tb00234.x

Dulay, H. C., Burt, M. K., \& Krashen, S. (1982). Language two. New York, N.Y.: Oxford University Press.

Durrant, P., \& Mathews-Aydınl,, J. (2011). A function-first approach to identifying formulaic language in academic writing. English for Specific Purposes, 30(1), 58-72. http://dx.doi.org/10.1016/j.esp.2010.05.002

Ferris, D. R. (2004). The "grammar correction" debate in L2 writing: Where are we, and where do we go from here? (And what do we do in the meantime...?). Journal of Second Language Writing, 13(1), 49-62. http://dx.doi.org/10.1016/j.jslw.2004.04.005

Gil, K. H., \& Marsden, H. (2010). Semantics before syntax: L2 knowledge of anyone by Korean speaking learners. In M. Iverson, J. Tiffany, I. Ivanov, J. Rothman, R. Slabakova, \& M. Tyzna (Eds.), Proceedings of the Mind-Context Divide Workshop (pp. 40-51). Somerville MA: Cascadilla Press.

Han, Z., \& Liu, Z. (2013). Input processing of Chinese by ab initio learners. Second Language Research, 29(2), 145-164. http://dx.doi.org/10.1177/0267658313479359 
Jiang, N. (2004). Semantic transfer and its implications for vocabulary teaching in a second language. The Modern Language Journal, 88(3), 416-432. http://dx.doi.org/10.1111/j.0026-7902.2004.00238.x

Kecskes, I. (2007). Formulaic language in English lingua franca. In I. Kecskes, \& L. Horn (Eds.), Explorations in Pragmatics: Linguistic, Cognitive and Intercultural Aspects (pp. 191-218). Berlin/New York: Mouton de Gruyter.

Ko, H., Perovic, A., Ionin, T., \& Wexler, K. (2008). Semantic universals and variation in L2 article choice. Proceedings of the 9th Generative Approaches to Second Language Acquisition Conference (GASLA 9), 118-129.

Krashen, S. D., \& Terrell, T. D. (1983). The natural approach. New York, NY: Alemany Press.

Lee, I. (2014). Teachers' reflection on implementation of innovative feedback approaches in EFL writing. English Teaching, 69(1), 23-39. http://dx.doi.org/10.15858/engtea.69.1.201403.23

Li, J., \& Schmitt, N. (2009). The acquisition of lexical phrases in academic writing: A longitudinal case study. Journal of Second Language Writing, 18(2), 85-102. http://dx.doi.org/10.1016/j.jslw.2009.02.001

Oak, S., \& Martin, V. S. (2003). Teaching English to Koreans. Seoul, South Korea: Hollym.

Pienemann, M. (1999). Language processing and second-language development: Processability theory. Amsterdam: John Benjamins Publishing Company. http://dx.doi.org/10.1075/sibil.15

Pienemann, M. (2005). Cross-linguistic aspects of processability theory. Amsterdam: John Benjamins Publishing Company. http://dx.doi.org/10.1075/sibil.30

Richards, J. C., \& Schmidt, R. (2013). Longman dictionary of language teaching \& applied linguistics (4th ed.). New York, NY: Routledge.

Schmitt, N. (Ed.). (2004). Formulaic sequences: Acquisition, processing, and use (vol. 9). Philadelphia, PA: John Benjamins Publishing.

Truscott, J. (1996). The case against grammar correction in L2 writing classes. Language Learning, 46(2), 327-369. http://dx.doi.org/10.1111/j.1467-1770.1996.tb01238.x

Truscott, J. (1999). The case for "the case against grammar correction in L2 writing classes": A response to $\begin{array}{lllll}\text { Ferris. Journal of Second Language Writing, } & \text { 8(2), }\end{array}$ http://dx.doi.org/10.1016/s1060-3743(99)80124-6

Tyson, R. E. (2003). Teaching composition at Korean universities: Focus on the writing process. In S. Oak, \& V. S. Martin (Eds.), Teaching English to Koreans (pp. 115-123). Seoul, South Korea: Hollym.

Van Beuningen, C. G., De Jong, N. H., \& Kuiken, F. (2012). Evidence on the effectiveness of comprehensive error correction in second language writing. Language Learning, 62(1), 1-41. http://dx.doi.org/10.1111/j.1467-9922.2011.00674.x

Watanabe, Y. (1996). Does grammar translation come from the entrance examination? Preliminary findings from $\begin{array}{lllll}\text { classroom-based } \quad \text { research. } & \text { Language } & \text { Testing, } & \text { 13(3), } & \text { 333. }\end{array}$ http://dx.doi.org/10.1177/026553229601300306

Wood, D. (2007). Mastering the English formula: Fluency development of Japanese learners in a study abroad context. JALT Journal, 29(2), 209.

Wood, D. (2008). Mandarin Chinese speakers in a study abroad context: Does acquisition of formulaic sequences facilitate fluent speech in English. The East Asian Learner, 3(2), 43-62.

Wood, D. (2009). Effects of focused instruction of formulaic sequences on fluent expression in second language narratives: A case study. Canadian Journal of Applied Linguistics, 12(1).

Wray, A. (2000). Formulaic sequences in second language teaching: Principle and practice. Applied linguistics, 21(4), 463-489. http://dx.doi.org/10.1093/applin/21.4.463

Zheng, L., \& Huang, J. (2010). A study of Chinese EFL learners' pragmatic failure and the implications for college English teaching. Polyglossia, 18, 41-54. 


\section{Appendix A}

Table A1. Formulaic expressions and their function

\begin{tabular}{|c|c|c|}
\hline Function & Native English Writers & Korean EFL Writers \\
\hline 1. Describe a Sequence & $\begin{array}{l}\text {-...is the first step... } \\
\text { - } \quad \text { In closing, }\end{array}$ & $\begin{array}{ll}\text { - } & \text { First, Second, Third, Forth } \\
\text { - } & \text { First of all, } \\
\text { - } & \text { Next, } \\
\text { - } & \text { Finally, }\end{array}$ \\
\hline 2. Compare and Contrast & $\begin{array}{l}\text { - } \\
\text { - } \\
\text { - ...as (different) as... } \\
\text { - } \quad \text { Caught between two worlds } \\
\text { community } \\
\text { - } \quad \text {...a common ground on which } \\
\text { to... } \\
\text { - } \quad \text { Mirroring their achievements }\end{array}$ & $\begin{array}{l}\text { - On the other hand, } \\
\text { - } \quad \text { On the contrary, } \\
\text { - In contrast, }\end{array}$ \\
\hline 3. Explain Cause and Effect & $\begin{array}{ll}\text { - } & \text { Due to... } \\
\text { - } & \text { Consequently, } \\
\text { - } & \text { Therefore, } \\
\text { - } & \text { Brought about by... }\end{array}$ & 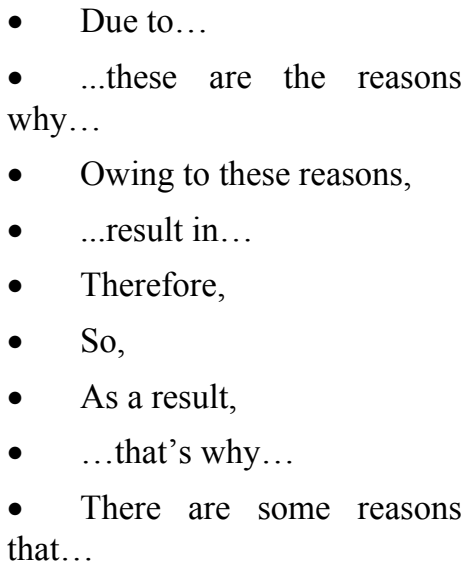 \\
\hline 4. Elaborate on a Concept & $\begin{array}{ll}\text { - } & \text { In particular, } \\
\text { - } & \text { For instance, } \\
\text { - } & \text { Take, for instance, }\end{array}$ & - For example, \\
\hline 5. Emphasize Importance & $\begin{array}{l}\text { - } \quad \text { Especially important... } \\
\text { - ...one of the most prominent } \\
\text { ideas... }\end{array}$ & $\begin{array}{ll}- & \text { Especially, } \\
\text { - } & \text { One of the most important } \\
& \text { is... }\end{array}$ \\
\hline 6. Express an Opinion & $\begin{array}{ll}\text { - } & \text { In my opinion, } \\
\text { - } & \text { Hopefully, } \\
\text { - } & \text { Fortunately, }\end{array}$ & $\begin{array}{l}\text { - In my opinion, } \\
\text { - } \quad \text {..the best way for me... }\end{array}$ \\
\hline 7. Present Another Perspective & $\begin{array}{ll}\text { - } & \text { In most people's eyes } \\
\text { - } & \text { In most cases } \\
\text { - } & \text { At the same time, } \\
\text { - } & \text { As explained by... }\end{array}$ & \\
\hline $\begin{array}{l}\text { 8. Express Degree of Intensity } \\
\text { or Certainty }\end{array}$ & $\begin{array}{ll}\text { - } & \text { Beyond a shadow of a doubt } \\
\text { - } & \text { In no way } \\
\text { - } & \text { To some extent, }\end{array}$ & \\
\hline
\end{tabular}




\begin{tabular}{|c|c|}
\hline & $\begin{array}{l}\text { - } \quad \text { On this level, } \\
\text { - } \quad \text {...just as importantly... } \\
\text { - } \quad \text { I would be hard-pressed to find } \\
\text { anyone... }\end{array}$ \\
\hline 9. Describe a Process & $\begin{array}{ll}\text { - } & \text {...thereby broadening one's... } \\
\text { - } & \text {...in such a way that... } \\
\text { - } & \text { In this manner, } \\
\text { - } & \text {...as a way to... } \\
\text { - } & \text { Because of the way... }\end{array}$ \\
\hline $\begin{array}{l}\text { 10. Reveal New and Unknown } \\
\text { Information to the Reader }\end{array}$ & $\begin{array}{l}\text { - } \text { Take, for instance, } \\
\text { - ...under the surface... } \\
\text { - It gives us a fresh new } \\
\text { perspective on... } \\
\text { - ...give us some insight into... }\end{array}$ \\
\hline 11. Involve the Reader & $\begin{array}{l}\text { - } \text { Open our eyes to... } \\
\text { - } \quad \text {...close our eyes to the } \\
\text { violence... } \\
\text { - } \quad \ldots \text { of our people... } \\
\text { - } \quad \text { One wonders how... } \\
\text { - } \quad \text {..provides us with... } \\
\text { - } \quad \ldots \text { shows us how... }\end{array}$ \\
\hline $\begin{array}{l}\text { 12. Put Examples Into Larger } \\
\text { Perspective }\end{array}$ & $\begin{array}{ll}\text { - } & \text { As a whole, } \\
\text { - } & \text {...draws together... } \\
\text { - } & \text {...as part of... } \\
\text { - } & \text { To put the argument simply, } \\
\text { - } & \text { Symbolic of. }\end{array}$ \\
\hline
\end{tabular}

\section{Copyrights}

Copyright for this article is retained by the author(s), with first publication rights granted to the journal.

This is an open-access article distributed under the terms and conditions of the Creative Commons Attribution license (http://creativecommons.org/licenses/by/3.0/). 